\title{
Adherence epitopes of Mycoplasma genitalium adhesin
}

\author{
OLIVER OPITZ and ENNO JACOBS*
}

Department for Microbiology and Hygiene, Institute for Medical Microbiology and Hygiene, Hermann-Herderstrasse 11, D-7800 Freiburg, Germany

(Received 18 February 1992; revised 11 May 1992; accepted 22 May 1992)

\begin{abstract}
The adherence-mediating sites of the $153 \mathrm{kDa}$ adhesin of Mycoplasma genitalium (MgPa-protein) were characterized at the amino acid sequence level using six monoclonal anti-MgPa antibodies which showed adherence-inhibiting activity. For characterization of the regions to which antibody bound, three segments of the adhesin (N-terminal region, a D1-domain located approximately in the middle of the molecule and a D2-domain located near to the $\mathrm{C}$-terminus) were synthesized as overlapping octapeptides. These regions were chosen in analogy to the three domains of Mycoplasma pneumoniae that are involved in the adhesion process. Whereas two monoclonal antibodies ( $\mathrm{mAb} 5 \mathrm{B11}$ and $\mathrm{mAb}$ 6F3) bound exclusively to an epitope in the $\mathrm{N}$-region, $\mathrm{mAb} 3 \mathrm{~B} 7$ and mAb 6A2 reacted with two distinct epitopes of the D2-domain only. Binding to short synthetic peptides of different regions was analysed for mAb 3A12 ( $\mathrm{N}$-region and D1-region) and mAb $2 \mathrm{B6}$ ( $\mathrm{N}$-region and D2-region). Close proximity of the $\mathrm{N}$-region and the D2-region in the native MgPa-protein of $M$. genitalium was indicated in a competitive ELISA test, using freshly harvested $M$. genitalium cells. Epitope mapping and competition experiments with monoclonal anti-MgPa antibodies revealed interesting differences in the adherence-mediating sites of $\mathrm{MgPa}$ and the adhesin (P1-protein) of $M$. pneumoniae. Whereas a three-dimensional arrangement of protein loops is suggested for both native adhesins, the MgPa-protein and the P1-protein adherence-mediating epitopes are located in non-homologous regions of these two related proteins. Thus, the two mycoplasma species appear adapted to different host epithelial cells, i.e. to those of the human urogenital tract as the main binding site for $M$. genitalium and to those of the respiratory tract as the binding site for $M$. pneumoniae.
\end{abstract}

\section{Introduction}

Adhesion to host cells of the mycoplasma species $M$. genitalium and $M$. pneumoniae is a prerequisite for colonization of epithelia and for further multiplication. The lack of a cell wall and therefore of any of the structures normally responsible for attachment of prokaryotes suggests that mycoplasmal adhesins are components of their cytoplasmic membranes. Recent studies on adhesins of $M$. pneumoniae and $M$. genitalium revealed species-specific differences, but common protein molecules which are the attachment sites of mycoplasmas to host cells (Razin \& Jacobs, 1992). Interestingly, these two different protein adhesins are both concentrated in specialized tip structures of adherent filamentous mycoplasma cells (Feldner et al., 1982; Hu et al., 1987).

A comparison of the molecular properties of the adhesin of $M$. genitalium (MgPa-protein) with the

\footnotetext{
* Author for correspondence. Tel. (761) 203 2156/7; fax (761) 203 2187.
}

Abbreviations: mAb, monoclonal antibody; pin, solid-phase carrier.
P1-adhesin of $M$. pneumoniae reveals: (i) the MgPaprotein, with a relative molecular mass of $153 \mathrm{kDa}$, is smaller than the P1-adhesin (170 kDa) (Mader et al., 1991); (ii) both proteins contain no cysteine residues indicating a flexible structure and (iii) both proteins possess a proline-rich $\mathrm{C}$-terminus indicating a rigid structure for the $\mathrm{C}$-terminal region; (iv) both proteins are immunodominant antigens during natural infections (Jacobs et al., 1991); and (v) matching the amino acid sequences of the $\mathrm{MgPa}$-protein of $\boldsymbol{M}$. genitalium and of the P1-protein of $M$. pneumoniae for maximum amino acid homology reveals 747 amino acids in common, which are clustered in extended regions (Mader et al., 1991). Inserts of single amino acids or even of protein loops of several amino acids (up to 13 amino acids in length) of the P1-protein are lacking in the smaller $\mathrm{MgPa}$-protein sequence; and (vi) moreover, structural similarities were found using computer-based predictions of membrane-anchoring helices according to Eisenberg et al. (1984). These membrane-associated domains of both proteins are located in corresponding regions of the primary sequences (Mader et al., 1991). 


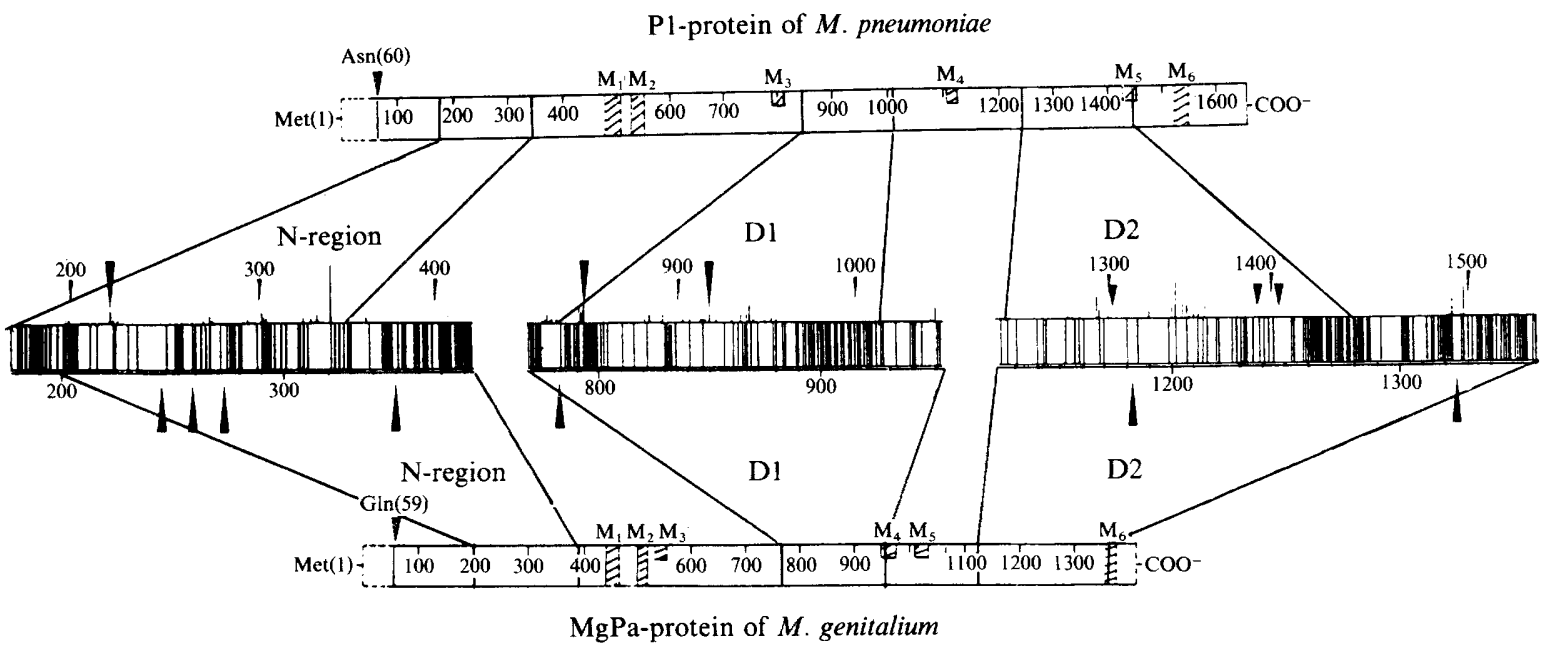

Fig. 1. The binding sites (arrowheads) of adherence-inhibiting monoclonal antibodies within the N-region, and the D1- and D2-domains of the MgPa-protein of $M$. genitalium and the P1-protein of $M$. pneumoniae (Gerstenecker \& Jacobs, 1990). Anti-MgPa $\mathrm{mAb}$ bound to non-homologous regions of the $M$. genitalium $\mathrm{MgPa}$ sequence compared to the $M$. pneumoniae $\mathrm{P} 1$ amino acid sequence. Homologous amino acids within the N-region, D1- and D2-domains of both proteins are connected and additional amino acids of the larger P1-protein are shown as spikes of length proportional to the number of amino acids involved. Almost all of the anti-P1-protein $\mathrm{mAbs}$ bound to these extra amino acid residues or to polypeptides with no corresponding sequence of the related $M$. genitalium adhesin sequence. The areas $\mathbf{M}_{1}-\mathbf{M}_{6}$ indicate predicted membrane-associated helices of both proteins according to Eisenberg et al. (1984).

In a recent study it was shown that the topographical arrangement of the P1-adherence-mediating complex is composed of three different protein loops. These contain adherence-mediating sites which are juxtaposed by protein folding to form the tertiary structure of the native P1-adhesin (Gerstenecker \& Jacobs, 1990).

Since the P1-protein and the MgPa-protein show close similarities, it was of interest to examine whether the functional adherent sites of the $\mathrm{MgPa}$-protein of $M$. genitalium are comparable with the known sites of the P1-protein of $M$. pneumoniae. By analogy to the strategy employed for P1-analysis, anti-MgPa adherence-inhibiting $\mathrm{mAbs}$ were established. The binding sites of these $\mathrm{mAbs}$ were characterized using synthetic octapeptides of three domains of the adhesin sequence of $M$. genitalium. Furthermore, the topology of defined epitopes in the native $\mathrm{MgPa}$-protein was characterized using a competitive enzyme immunoassay with viable $M$. genitalium cells.

\section{Methods}

Peptide synthesis. $N^{\alpha}$-(9-fluorenylmethyloxycarbonyl) (FMOC) amino acid chemistry (Dryland \& Sheppard, 1986; Sheppard, 1986) was used for the preparation of synthetic octapeptides as antigens. Peptides with an overlapping sequence of seven amino acids were synthesized on to solid phase carriers (pins) using the epitope scanning kit (CRB, Cambridge) according to the method of Geysen et al. (1984).

For analysis of the mAb binding sites, three different regions of the $\mathrm{MgPa}$-protein were synthesized which corresponded to the adherence domains of the P1-protein of $M$. pneumoniae (Fig. 1): the N-region (amino acids 200 to 384), the D1-region (769 to 954) and the D2-region (1123 to 1360) (Dallo et al., 1989; Gerstenecker \& Jacobs, 1990).

Adherence-inhibiting $m A b s$. Two different antigen preparations were used for the immunization of 3-month old Balb/c mice. For the first injection freshly harvested glass-adherent $M$. genitalium cells (strain $G$ 37) cultured in Hayflick's modification of Edward's medium (Hayflick, 1965) were injected intraperitoneally (1 mg total protein per injection). After 1 month two further intraperitoneal injections of the purified MgPa-protein (100 $\mu \mathrm{g}$ per injection) (Mader et al., 1991) were applied at weekly intervals. All preparations were used without any adjuvant. Four days after the final $\mathrm{MgPa}$ injection spleen cells were removed for fusion with X63-Ag8.653 myeloma cells (de St. Groth \& Scheidegger, 1980). Viable hybridoma clones were recovered from four fusion experiments.

The secreted antibodies were screened for the following activities: (i) binding to purified MgPa-protein or to sonicated whole mycoplasma cells, in enzyme immunoassays (Jacobs et al., 1991); (ii) binding to MgPa-protein in immunoblots of M. genitalium protein (Jacobs et al., 1986); (iii) adherence inhibition of sheep red blood cells to viable M. genitalium cells (Jacobs et al., 1985); and (iv) positive immunofluorescence activity directed to the distinct tip structure of $M$. genitalium cells using glass-adherent mycoplasmas (Feldner et al., 1982).

The appropriate hybridomas were subcloned using a limiting dilution technique and cultured in vitro. Monoclonal antibodies were precipitated from the culture supernatants, dialysed and stored at $4{ }^{\circ} \mathrm{C}$ (Gerstenecker \& Jacobs, 1990).

The immunoglobulin subclasses of the different $\mathrm{mAbs}$ were determined using rabbit anti-mouse reagents according to the manufacturer's instructions (ICN-Immunobiologicals).

Epitope scanning. Supernatants from the different hybridoma clones were enriched with blocking buffer $[1 \%(w / v)$ BSA, $1 \%(w / v)$ ovalbumin and $1 \%(\mathrm{v} / \mathrm{v})$ Tween 20 in PBS $(0.14 \mathrm{M}-\mathrm{NaCl}, 0.01 \mathrm{M}$-sodium phosphate, $\mathrm{pH} 7 \cdot 2$ )] and incubated overnight with the solid-phase (pin) -immobilized octapeptides at $4^{\circ} \mathrm{C}$. The pins were washed with PBS/Tween 20 and incubated with an alkaline phosphatase-conjugated secondary antibody (goat anti-mouse immunoglobulins, Dianova) 
diluted in blocking buffer. After final washing, the pins were incubated in substrate solution (10 mg $p$-nitrophenyl phosphate $\mathrm{ml}^{-1}$ in diethanolamine buffer, $\mathrm{pH} 9.6$ ) for $1 \mathrm{~h}$ at $37^{\circ} \mathrm{C}$ (Gerstenecker \& Jacobs, 1990), and phosphatase activity was measured as the increase in $A_{405}$ (Titertek Multiscan, Flow Laboratories).

mAb competition experiments. Glass-adherent $M$. genitalium cells were scraped off and washed with PBS. The freshly harvested cell suspension was adjusted to a protein concentration of $100 \mu \mathrm{g} \mathrm{ml}^{-1}$. Aliquots of the cell suspension $(100 \mu \mathrm{l})$ were incubated on microtitre plates (pretreated with poly(L-lysine) $(50 \mu \mathrm{g}$ per well) and glutaraldehyde $(100 \mu \mathrm{l}$ of a $20 \%, \mathrm{v} / \mathrm{v}$, solution in deionized water) for $2 \mathrm{~h}$ at $37^{\circ} \mathrm{C}$ under gentle rotation (Gerstenecker \& Jacobs, 1990). The plates were washed with pre-warmed PBS. Remaining aldehyde groups were blocked with $3 \% \mathrm{BSA} / \mathrm{PBS}$ for $1 \mathrm{~h}$ at $37^{\circ} \mathrm{C}$.

Unlabelled $\mathrm{mAb}(100 \mu \mathrm{l}$ per well $)$ was added and incubated for $2 \mathrm{~h}$ at $37^{\circ} \mathrm{C}$ under maximum antigen saturation conditions. Biotin-labelled $\mathrm{mAb}$ (500 $\mathrm{ng}$ in $20 \mu \mathrm{l}$ per well) was then added and incubated for $1 \mathrm{~h}$ at $37^{\circ} \mathrm{C}$. The plates were washed three times with PBS $/ 0.05 \%$ Tween- 20 . The binding of the biotin-labelled $\mathrm{mAb}$ was detected with streptavidin/ peroxidase complexes (200 ng per well, Sigma). Substrate $\left(\mathrm{H}_{2} \mathrm{O}_{2} /\right.$ tetramethylbenzidine) was added and colour development $\left(A_{450}\right)$ measured after incubation for $30 \mathrm{~min}$ at room temperature.

\section{Results}

Four fusion experiments revealed 181 hybridoma clones which produced antibodies reacting with the sonicated $M$. genitalium whole cell antigen preparation in an enzyme immunoassay. Sixty-four of these supernatants also recognized the purified $\mathrm{MgPa}$-protein used as a defined antigen. Only six of these latter antibodies inhibited the adherence of sheep erythrocytes to viable $M$. genitalium cells in an adherence inhibition assay (Table 1). Additionally, these adherence inhibiting antibodies showed a specific binding to the $\mathrm{MgPa}-$ protein in Western immunoblots and a distinct positive signal in the immunofluorescence test (results not shown). Five of these mAbs belonged to the $\mathrm{IgG}_{1} \kappa$ immunoglobulin subclass; $\mathrm{mAb} 5 \mathrm{~B} 11$ is an IgM antibody (Table 1).

For epitope analysis the six adherence-inhibiting mAbs were tested for binding to overlapping octapeptides representing three $\mathrm{MgPa}$ regions analogous to the adherence-mediating sites of the P1-protein of M. pneumoniae (Fig. 1). The first region (N-region) is located near the $\mathrm{N}$-terminus of the mature $\mathrm{MgPa}$ protein, in front of two predicted membrane-associated helices $\left(M_{1}\right.$ and $M_{2}$ in Fig. 1). The D1-domain (D1) is located almost in the middle of the $\mathrm{MgPa}$-amino acid sequence, whereas the D2-domain (D2) is located next to the hydrophobic C-terminal $\mathbf{M}_{6}$-sequence.

Binding of $\mathrm{mAbs}$ to overlapping immobilized octapeptides was distinct and specific (Fig. 2). $\mathrm{mAb}$ 6F3 exclusively recognized an octapeptide $\left[\mathrm{NH}_{2}-(245)-\mathrm{P}-\mathrm{V}-\right.$ $\mathrm{K}-\mathrm{D}-\mathrm{S}-\mathrm{S}-\mathrm{K}-\mathrm{Q}$ ] located in the $\mathrm{N}$-region (Table 1). Antibody 5B11 also bound to an N-region sequence
Table 1. Different anti-MgPa monoclonal antibodies ( $\mathrm{mAb}$ ) with positive adherence inhibition in the adherence-inhibiting assay $(A I A)$ and their activity to synthetic overlapping solidphase octapeptides of the $\mathrm{N}$-region, D1- and D2-domains

\begin{tabular}{|c|c|c|c|c|c|}
\hline \multirow[b]{2}{*}{$\mathrm{mAb}$} & \multirow[b]{2}{*}{$\begin{array}{l}\text { Ig-sub- } \\
\text { classes }\end{array}$} & \multirow[b]{2}{*}{ AIA } & \multicolumn{3}{|c|}{ First amino acid of the octapeptide in: ${ }^{*}$} \\
\hline & & & $\begin{array}{c}\text { N-region } \\
(200-384)\end{array}$ & $\begin{array}{l}\text { D1-domain } \\
\text { (769-954) }\end{array}$ & $\begin{array}{c}\text { D2-domain } \\
(1123-1360)\end{array}$ \\
\hline $6 \mathrm{~F} 3$ & $\operatorname{IgG}_{1}$ & + & 245 & & \\
\hline $3 \mathrm{~A} 12$ & $\mathrm{IgG}_{1}$ & + & 259 & 782 & \\
\hline $5 B 11$ & IgM & + & 274 & & \\
\hline 2B6 & $\operatorname{IgG}_{1}$ & + & 349 & & 1183 \\
\hline $3 B 7$ & $\operatorname{lgG}_{1}$ & + & & & 1183 \\
\hline $6 \mathrm{~A} 2$ & $\mathrm{IgG}_{1}$ & + & & & 1323 \\
\hline
\end{tabular}

* Amino acids are numbered from the $\mathrm{N}$-terminus.

$\left[\mathrm{NH}_{2}-(274)-\mathrm{A}-\mathrm{K}-\mathrm{A}-\mathrm{L}-\mathrm{K}-\mathrm{V}-\mathrm{E}-\mathrm{V}\right]$ located near to the mAb 6F3 binding site (Table 1). Similarly, mAb 6A2 $\left[\mathrm{NH}_{2}-\right.$ (1323)-P-Q-T-Q-Q-F-I-P] and $\mathrm{mAb} 3 \mathrm{~B} 7$ [ $\mathrm{NH}_{2}-(1183)-\mathrm{S}-$ E-G-L-K-E-E-T] bound to different octapeptides, but located in the D2-domain. In contrast, each of the mAbs $3 \mathrm{~A} 12$ and $2 \mathrm{~B} 6$ reacted with two distinct octapeptides. $\mathrm{mAb} 2 \mathrm{~B} 6$ bound to an octapeptide $\left[\mathrm{NH}_{2}-(349)-\mathrm{S}-\mathrm{E}-\mathrm{N}-\mathrm{H}-\right.$ T-A-F-G] of the N-region and to an octapeptide of the D2-domain [ $\left.\mathrm{NH}_{2}-(1183)-\mathrm{S}-\mathrm{E}-\mathrm{G}-\mathrm{L}-\mathrm{K}-\mathrm{E}-\mathrm{E}-\mathrm{T}\right]$. The latter binding site was also the binding site of $\mathrm{mAb} 3 \mathrm{~B} 7 . \mathrm{mAb}$ $3 \mathrm{~A} 12$ bound to an amino acid sequence within the $\mathrm{N}$-region $\left[\mathrm{NH}_{2}-(259)-\mathrm{T}-\mathrm{T}-\mathrm{A}-\mathrm{S}-\mathrm{S}-\mathrm{M}-\mathrm{S}-\mathrm{S}\right]$ and to the D1-domain sequence [ $\mathrm{NH}_{2}$-(782)S-P-S-T-S-A-S-S]. To exclude the possible presence of two different antibodyproducing hybridoma cell lines within clones $\mathrm{mAb} 2 \mathrm{~B} 6$ and $\mathrm{mAb} 3 \mathrm{Al} 12$, these were further subcloned and retested. The dual binding sites of both $\mathrm{mAbs}$ were confirmed.

For investigation of the topographical arrangement of the different $\mathrm{mAb}$ binding sites in the native $\mathrm{MgPa}$ protein, the adherence-inhibiting $\mathrm{mAbs}$ were tested in a competitive immunoasssay using intact $M$. genitalium cells as antigen. Unlabelled mAbs were preincubated with $M$. genitalium cells under antigen saturation conditions. In a second incubation step biotinylated $\mathrm{mAbs}$ competing with the unlabelled $\mathrm{mAb}$ for $\mathrm{MgPa}$ binding sites were applied (Table 2 and Fig. $3 a$ ). It was found that: (i) preincubation with mAb 2B6 (dual binding sites in the $\mathrm{N}$-region and the $\mathrm{D} 2$-domain) completely inhibited binding of $\mathrm{mAbs} 6 \mathrm{~A} 2$ (D2-domain) and 3B7 (D2-domain), and partially inhibited binding of mAB 5B11 (N-region); (ii) the IgM antibody mAb 5B11 (N-region) blocked the binding of all other adherenceinhibiting mAbs; (iii) mAb 6A2 (D2-domain) inhibited the binding of $\mathrm{mAbs} 2 \mathrm{~B} 6,3 \mathrm{~B} 7,5 \mathrm{~B} 11$ and $6 \mathrm{~F} 3$ (Fig. 3); (iv) preincubation of $M$. genitalium cells with $\mathrm{mAb} 3 \mathrm{~B} 7$ (only one binding site in the D2-domain which is also 


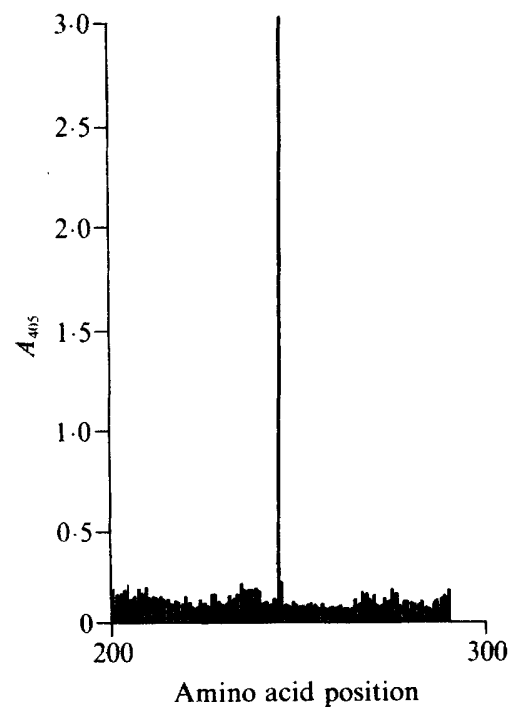

Fig. 2. ELISA activity of mAb $6 \mathrm{~F} 3$ culture supernatants with synthetic, overlapping pin-immobilized octapeptides of the $\mathrm{MgPa}$ amino acid sequence (amino acids 200 to 280 ) of the $\mathbf{N}$-region. Each bar represents the activity to a single octapeptide of this sequence.

Table 2. Competition-ELISA for topological mapping of the $M g P A$-protein adhesin structure with viable $M$. genitalium cells and adherence-inhibiting $m A$ bs

Inhibition (I) was defined arbitrarily as follows: $I \leqslant 20 \%$, no inhibition ( 0$) ; \mathrm{I}=21-50 \%$, partial inhibition $(+/-) ; \mathrm{I}>50 \%$, inhibition ( + ). Undisturbed binding of each mAb was used as a non-competition control and is defined as having $100 \%$ binding efficiency and producing $0 \%$ inhibition. The test included selfcompetition controls.

\begin{tabular}{ccccccc}
\hline \hline & \multicolumn{7}{c}{ Inhibition of probed biotin-labelled mAb:* } \\
\cline { 2 - 7 } $\begin{array}{c}\text { Preincubation } \\
\text { with mAb }\end{array}$ & 5B11 & $6 \mathrm{~F} 3$ & $3 \mathrm{~A} 12$ & $2 \mathrm{~B} 6$ & $3 \mathrm{~B} 7$ & $6 \mathrm{~A} 2$ \\
& (N) & (N) & (N/D1) & (N/D2) & (D2) & (D2) \\
\hline 5B11 & + & + & + & + & + & + \\
6F3 & $+1-$ & + & $+1-$ & 0 & 0 & $+1-$ \\
3A12 & $+1-$ & + & + & 0 & $+1-$ & $+1-$ \\
2B6 & $+1-$ & + & 0 & + & + & + \\
3B7 & + & $+1-$ & 0 & $+1-$ & + & + \\
6A2 & + & + & $+1-$ & + & + & + \\
\hline \hline
\end{tabular}

* N, N-region; D1, D1-domain; D2, D2-domain.

recognized by $\mathrm{mAb} 2 \mathrm{~B} 6$ ) partially inhibited binding of $\mathrm{mAb} 2 \mathrm{~B} 6$ and completely inhibited binding of $\mathrm{mAbs}$ $6 \mathrm{~A} 2$ and $5 \mathrm{~B} 11$; (v) preincubation with $\mathrm{mAb} 6 \mathrm{~F} 3$ resulted in no or only partial inhibition of the binding of other $\mathrm{mAbs}$. On the other hand, binding of $\mathrm{mAb} 6 \mathrm{~F} 3$ was completely inhibited by all other mAbs, indicating that its binding site is probably located on a protein segment that is obscured under in vivo conditions by other, more surface-exposed, binding sites; and (vi) mAb $3 \mathrm{~A} 12$ whose $\mathrm{N}$-region binding site is located between those of

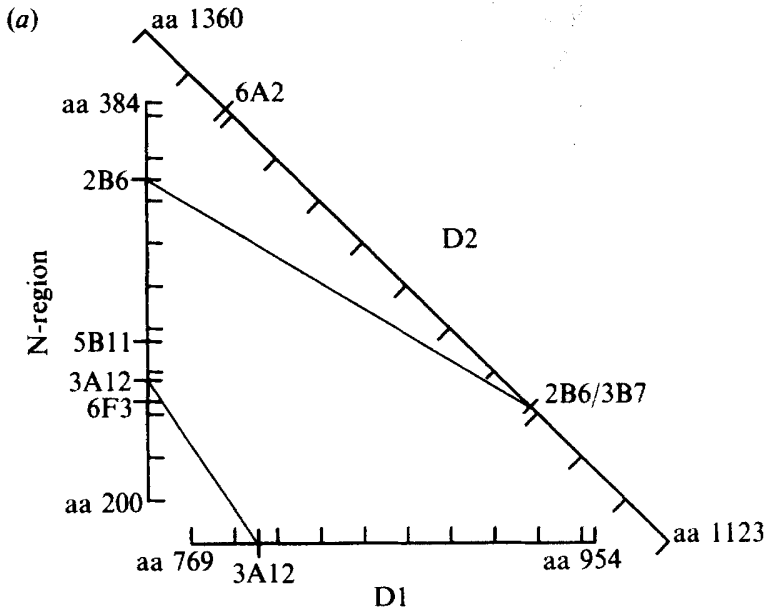

(b)

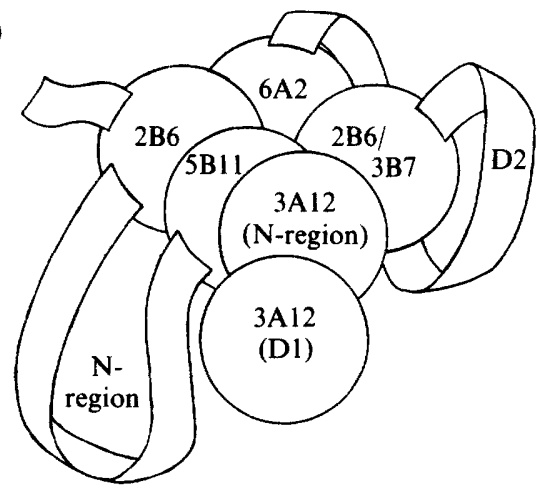

Fig. 3. The binding sites of the different adherence inhibiting $m A b s$ on the N-region, the D1- and D2-domains and the possible topographical arrangement of these positions according to the analysis of the results of competitive ELISA (Table 2) in (a) a two-dimensional and (b) a threedimensional cartoon. The dual binding sites of $\mathrm{mAbs} 2 \mathrm{~B} 6$ and $3 \mathrm{~A} 12$ are connected in $(a)$.

mAb 5B11 (N-region) and mAb 6F3 (N-region) on the linear amino acid sequence, showed a more efficient blocking of $\mathrm{mAb} 6 \mathrm{~F} 3$ than $\mathrm{mAb} 5 \mathrm{~B} 11$. Since $\mathrm{mAb} 3 \mathrm{~A} 12$ has a further binding site within the D1-domain, it was of interest to examine whether its binding could be blocked by the D2-binding mAbs (6A2, 2B6 and 3B7). However, none of these were able to block binding completely. In contrast, two of the mAbs with binding sites in the $\mathrm{N}$-region (mAb 5B11 and mAb 6F3) did block mAb $3 \mathrm{~A} 12$ binding, whereas mAb $2 \mathrm{~B} 6$, which bound on the $\mathrm{C}$-terminal end of the $\mathrm{N}$-region, did not.

\section{Discussion}

In this study six adherence-inhibiting monoclonal anti$\mathrm{MgPa}$ antibodies were used for epitope mapping and topological studies of adherence sites of the $\mathrm{MgPa}$ adhesin of $M$. genitalium. At least two domains, the 
$\mathrm{N}$-terminal region and the D2-domain, which is located near the C-terminal end, seem to be involved in the adherence process. mAbs $2 \mathrm{~B} 6$ and $5 \mathrm{~B} 11$, both with $\mathrm{N}$-region binding sites, and mAbs 6A2 and 2B6 (and 3B7) with D2-domain binding sites recognize epitopes which cover the 'corners' of the still hypothetical proposed adherence complex (Fig. 3b). Moreover, with this arrangement the binding sites for the adherenceinhibiting mAbs might be brought into close contact by protein folding. This hypothesis is supported by the results of competition experiments, which showed maximum reciprocal inhibition between mAbs with binding sites in the $\mathrm{N}$-region and the D2-domain. The mapping experiments with epitopes are helpful for ready identification and further characterization of molecular structures with particular biological functions, i.e. adherence sites. Mapping results with antibodies recognizing more than one epitope may be interpreted as follows. (i) Since antibodies are mainly directed to discontinuous binding sites (van Regenmortel, 1989), the antibody response may be directed to more than one amino acid sequence if the avidity of the mAb is high enough to allow firm binding to the different fragments. These fragments may be located on different protein loops in close proximity, each contributing short amino acid sequences to the complete epitope recognized by the $\mathrm{mAb}$. (ii) A second reasonable explanation may be that both binding sites contain closely related or identical amino acid sequences. With respect to mAb 2B6, conformational binding of the antibody would support the hypothesis of close contact between the $\mathrm{N}$-region and the D2-domain. However, it cannot be excluded that the first two identical $\mathrm{N}$-terminal amino acid residues of the octapetides [i.e. serine and glutamic acid, underlined within the octapeptide sequences (see Results)] may be sufficient for recognition by $\mathrm{mAb} 2 \mathrm{~B} 6$. This would indicate binding to two similar epitopes in the $\mathrm{MgPa}$ protein that are located at different sites in this polypeptide. In a first replacement experiment in which the negatively charged amino acid $\mathrm{NH}_{2}-(1184)$ glutamic acid was exchanged by the non-polar amino acid alanine in both peptides, it was shown that the antibody completely lost the capacity to react with the modified epitopes (results not shown). This may indicate that the negatively charged amino acid in this position is an essential contact residue in the mAb $2 \mathrm{~B} 6$ recognition site. Since both modified peptides totally lost their antigenicity, it seems to be more likely that mAb $2 \mathrm{~B} 6$ is directed towards a very short amino acid sequence, rather than towards a discontinuous epitope, composed of different amino acids from both octapeptides. Since the signal intensity of this mAb versus the $\mathrm{N}$-region peptide was about one-third higher than that for the D2-domain peptide ( $\mathrm{N}$-region $A_{405}=3.0$ compared to
D2-domain $A_{405}=2 \cdot 1$ ), it has to be shown whether further serine-glutamic acid-attached amino acid residues may contribute to the elevated $\mathrm{N}$-region signal.

Epitope mapping revealed an unexpected result: $\mathrm{mAb}$ $3 \mathrm{~B} 7$ bound to the $\mathrm{NH}_{2}-(1183)$-octapeptide which was also one of the binding sites of $\mathrm{mAb} 2 \mathrm{~B} 6$. The inhibition experiments with these two mAbs showed that mAb 2B6 was able to block the binding of $m A b 3 B 7$ completely. On the contrary, preincubation with mAb $3 B 7$ resulted only in a partial inhibition of $\mathrm{mAb} 2 \mathrm{~B} 6$ binding, also indicating a strong affinity of $\mathrm{mAb} 2 \mathrm{~B} 6$ for the N-region binding site under in vivo conditions. More interestingly, since $\mathrm{mAb} 3 \mathrm{~B} 7$ was only partially able to block $\mathrm{mAb} 2 \mathrm{~B} 6$ binding, it seems reasonable to assume that the binding site of $\mathrm{mAb} 3 \mathrm{~B} 7$ is not directed to the first two amino acids of this octapeptide $\left(\mathrm{NH}_{2}-\mathrm{S}-\mathrm{E}\right)$. mAb $3 \mathrm{~B} 7 \mathrm{might}$ therefore be able to block mAb 2B6's D2-binding site sterically.

In contrast to the close proximity of the $\mathrm{N}$-region and the D2-domain, one can only speculate about the location of the D1-domain in respect to the other two domains. One mAb (3A12) could be established with binding sites in the $\mathrm{N}$ - and in the D1-domain. Comparing the amino acid sequences of these octapeptides $\left[\mathrm{NH}_{2}\right.$-(782)-S-P-S-T-S-A-S-S] and [ $\mathrm{NH}_{2}$-(259)-T-T-A-SS-M-S-S], the A-S-S residues were present in both peptides. The activity of this $\mathrm{mAb}$ to these two peptides seemed similar $\left(A_{405}=3.0\right)$, indicating that mAb $3 \mathrm{~A} 12$ could not discriminate between the two different epitopes. The competition experiments showed that $\mathrm{mAb} 3 \mathrm{~A} 12$ was not able to block the binding of mAb 2B6 and could only partially inhibit binding of mAbs $6 \mathrm{~A} 2$, $3 \mathrm{~B} 7$ and $5 \mathrm{~B} 11$. If the binding site of $\mathrm{mAb} 3 \mathrm{~A} 12$ is not located within the main adherence complex, this would also imply that the D1-domain (second binding site of $\mathrm{mAb} 3 \mathrm{~A} 12)$ does not contribute to the adherence complex. This adhesin complex may therefore differ from the adherence complex of the P1-protein of $M$. pneumoniae (Fig. 1). Furthermore, comparing the binding specificities of the anti-MgPa mAbs with those recently published for adherence-inhibiting anti-P1 mAbs, established against $M$. pneumoniae (Gerstenecker \& Jacobs, 1990), it was found that: (i) all the defined binding sites of the different $M$. genitalium-inhibiting mAbs were located in non-homologous regions, in comparison to the amino acid sequences of the P1-protein; and (ii) that all different binding sites of adherenceinhibiting $\mathrm{mAbs}$ which were established against $M$. pneumoniae are located on non-homologous regions or even additional protein loops of the larger P1-protein of M. pneumoniae (Fig. 1). Moreover, cross-reaction experiments using anti-adherence mAbs, established against $M$. genitalium, showed no adherence inhibition activity of $M$. pneumoniae to erythrocytes. One non-adherence- 
inhibiting anti- $\mathrm{MgPa} \mathrm{mAb}$ showed a cross-reactivity with the P1-protein of $M$. pneumoniae in a Western immunoblot and a strong $M$. pneumoniae adherenceinhibiting activity (results not shown).

One may therefore speculate that the two species selected a common 'ancestor' class of proteins for adherence purposes when colonizing different compartments of the host, i.e. epithelial cells of the urogenital tract and of the respiratory tract by $M$. genitalium and $M$. pneumoniae respectively. Host receptor structures might be quite different, so that differing adaptation of adhesin binding sites was necessary. Whereas the receptor sites of $M$. pneumoniae are known to be glycoproteins and glycolipids, the uroepithelial receptor sites of $M$. genitalium are still undefined (for detailed information see the review of Razin \& Jacobs, 1992). Such an adaptation to different epithelial cells might be enhanced by a flexible adherence complex, composed of different surface-exposed loops.

\section{References}

Dallo, S. F., Chavoya, A., Su, C. J. \& Baseman, J. B. (1989). DNA and protein sequence homologies between the adhesins of $M y c o-$ plasma genitalium and Mycoplasma pneumoniae. Infection and Immunity 57, 1059-1065.

Dryland, A. \& Sheppard, R. C. (1986). Peptide synthesis. Part 8. A system for solid-phase synthesis under low pressure continuous flow conditions. Journal of the Chemical Society Perkin Transactions I, 125-137.

Eisenberg, D., Schwarz, E., Komaromy, M. \& Wall, R. (1984). Analysis of membrane and surface protein sequences with the hydrophobic moment plot. Journal of Molecular Biology 179, 125-142.
Feldner, J., GöBel, U. \& BREDT, W. (1982). Mycoplasma pneumoniae adhesin localised to tip structure by monoclonal antibody. Nature, London 298, 765-767.

GersteneCKER, B. \& JACOBS, E. (1990). Topological mapping of the P1-adhesin of Mycoplasma pneumoniae with adherence-inhibiting monoclonal antibodies. Journal of General Microbiology 136, 471-476.

Geysen, H. M., Meloen, R. H. \& Barteling, S. J. (1984). Use of peptide synthesis to probe viral antigens for epitopes to a resolution of a single amino acid. Proceedings of the National Academy of Sciences of the United States of America 81, 3998-4002.

HAYFLICK, L. (1965). Tissue cultures and mycoplasmas. Texas Reports on Biology and Medicine 23, 285-303.

Hu, P. C., Schaper, U., Collier, A. M., Clyde, W. A., JR, Horikawa, M., Huang, Y. S. \& Barile, F. M. (1987). A Mycoplasma genitalium protein resembling the Mycoplasma pneumoniae attachment protein. Infection and Immunity 55, 1126-1131.

JACOBS, E., SCHÖPPERLE, K. \& BREDT, W. (1985). Adherence inhibition assay: a specific serological test for detection of antibodies to Mycoplasma pneumoniae. European Journal of Clinical Microbiology 4 , 113-118.

JACOBS, E., BENNEWITZ, A. \& BREDT, W. (1986). Reaction pattern of human anti-Mycoplasma pneumoniae antibodies in enzyme-linked immunosorbent assays and immunoblotting. Journal of Clinical Microbiology 23, 517-522.

JACOBS, E., WATTER, T., SChaEFer, H. E. \& BREDT, W. (1991) Comparison of host responses after intranasal infection of guineapigs with Mycoplasma genitalium or with Mycoplasma pneumoniae. Microbial Pathogenesis 10, 221-229.

Mader, B., Hu, P. C., Huang, C. H., SChIlz, E. \& JaCobs, E. (1991). The major MgPa-adhesin of Mycoplasma genitalium. Zentralblatt für Bakteriologie 274, 507-513.

RAZIN, S. \& JACOBS, E. (1992). Mycoplasma adhesion. Journal of General Microbiology 138 , 407-422.

VAN RegenMortel, M. H. V. (1989). Structural and functional approaches to the study of protein antigenicity. Immunology Today 10, 266-272.

DE St. Groth, F. S. \& Scheidegger, D. (1980). Production of monoclonal antibodies: strategy and tactics. Journal of Immunological Methods 35, 1-21.

SHEPPARD, R. C. (1986). Modern methods of solid-phase peptide synthesis. Science Tools 33, 9-16. 